\title{
MONITORING DAN ANALISIS JADWAL PROYEK MENGGUNAKAN METODE PERFORMANCE INTENSITY DAN CPM PADA PROYEK HOTEL
}

\author{
Ivan Pratama Setiadi ${ }^{1}$, Andi $^{2}$
}

\begin{abstract}
ABSTRAK: Ada sebuah metode penjadwalan baru yang dikembangkan tahun 2007 oleh Murray B. Woolf, yaitu Performance Intensity. Metode ini mempunyai dua variabel utama yaitu duration days dan time consumption. Penelitian ini bertujuan untuk melakukan monitoring dan analisa dengan menggunakan metode Performance Intensity dan CPM dengan dan mengetahui perbandingan analisa tanggal akhir sebuah proyek menggunakan metode Performance Intensity dengan metode penjadwalan CPM yang lebih dulu digunakan. Penelitian ini mempunyai batasan yaitu pekerjaan struktur, dinding dan tangga. Untuk melakukan penelitian ini diperlukan jadwal rencana sebagai acuan. Selain itu diperlukan data start date, finish date, persentase selesai tiap aktivitas yang didapat dari hasil monitoring setiap hari dan dilakukan analisa perbandingan mingguan dengan jadwal rencana. Jadwal rencana awal proyek selama 189 hari. Penelitian dilakukan selama 10 minggu dimulai dari tanggal 15 September 2014. Hasil dari penelitian adalah terdapat perbedaan analisa tanggal akhir antara metode Performance Intensity dengan metode CPM. Analisa tanggal akhir Performance Intensity mempunyai range antara 123-185 hari, sedangkan analisa metode CPM mempunyai range 175-199 hari. Perbedaaan range analisa prediksi tanggal berakhirnya proyek disebabkan metode Performance Intensity menggunakan laju pekerjaan kumulatif rata-rata sebagai tolak ukurnya yang selalu berubah-ubah tiap periode.
\end{abstract}

Kata kunci: penjadwalan, performance intensity, cpm, analisa

\section{PENDAHULUAN}

Penjadwalan merupakan salah satu tantangan dalam pekerjaan sebuah proyek. Apabila tidak diperhatikan secara serius, dapat mengakibatkan durasi proyek menjadi lebih lama dari yang direncanakan dan pembengkakan biaya proyek. Oleh karena itu, penting sekali adanya perencanaan dan pengendalian suatu jadwal proyek yang terstruktur dan selalu dikontrol setiap harinya.

Pada saat ini banyak terdapat metode penjadwalan proyek, contohnya Critical Path Method (CPM), Program Evaluation and Review Technique (PERT), Gantt Chart, Line of Balance (LOB). Selain itu, ada sebuah metode penjadwalan baru yang coba dikembangkan oleh Murray B. Woolf pada tahun 2007. Metode ini disebut Performance Intensity. Metode ini memberikan perhitungan laju pekerjaan tiap aktivitas sehingga dapat diketahui apakah aktivitas tersebut

\footnotetext{
${ }^{1}$ Mahasiswa Pascasarjana Universitas Kristen Petra, ivanps0908@gmail.com

${ }^{2}$ Dosen Universitas Kristen Petra,andi@petra.ac.id
} 
mengalami keterlambatan atau tidak. Dengan adanya hal tersebut, diharapkan suatu proyek dapat dikontrol dengan lebih mudah dengan diketahuinya sebuah keterlambatan ada ataupun tidak sedari awal.

\section{TINJAUAN PUSTAKA}

Penjadwalan proyek merupakan proses pemanfaatan waktu yang tersedia untuk melaksanakan pekerjaan dalam rangka menyelesaikan proyek hingga tercapai hasil yang diinginkan dengan mempertimbangkan keterbatasan yang ada (Husein, 2009). Ada proses planning, monitoring, analisa yang terdapat di dalamnya.

Planning dalam proyek konstruksi dilakukan untuk menentukan aktivitas apa saja yang akan dilakukan di dalam proyek. Langkah-langkah yang dilakukan dalam planning yaitu :

- WBS (Work Breakdown Structure) aktivitas proyek.

- Penyusunan rencana kerja proyek.

- Estimasi durasi aktivitas.

- Menentukan metode penjadwalan. (Performance Intensity dan CPM)

Work Breakdown Structure (WBS) dilakukan untuk memecah suatu proyek yang tentu saja sangat kompleks menjadi susunan aktivitas - aktivitas pekerjaan sehingga lebih mudah untuk dikontrol.

Penyusunan rencana kerja proyek dimaksudkan untuk menentukan tahapan/urutan aktivitas kerja dalam melaksanakan proyek. Urutan aktivitas ini diperlukan untuk menggambarkan hubungan antar berbagai aktivitas yang ada dalam proses pelaksanaan proyek (Proboyo, 1998). Hubungan antar aktivitas proyek dapat dinyatakan dengan finish to start, start to start, finish to finish, start to finish, dengan lag dapat dilihat pada Gambar 1.

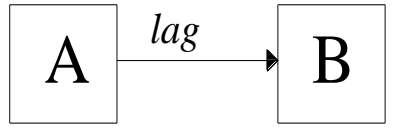

Finish to start

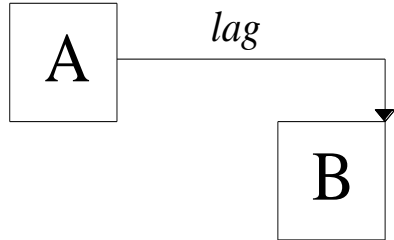

Finish to finish

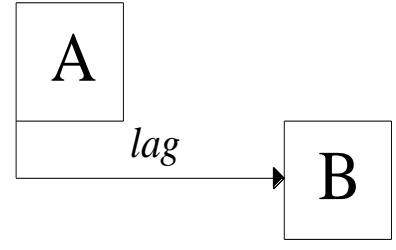

Start to start

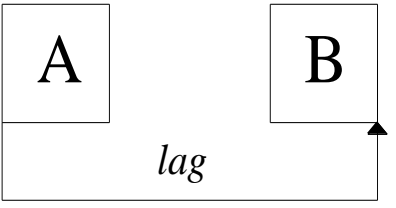

Start to finish

Gambar 1. Hubungan antar Aktivitas

Estimasi durasi aktivitas adalah memperkirakan panjang waktu yang diperlukan untuk menyelesaikan aktivitas tersebut. Estimasi durasi aktivitas dihitung berdasarkan pada perhitungan volume pekerjaan dan produktivitas tenaga kerja. (Proboyo, 1998)

Performance Intensity merupakan metode penjadwalan barchart yang dimodifikasi dengan menambahkan rumus di dalamnya. Performance intensity adalah perhitungan yang dilakukan untuk mengetahui laju pekerjaan proyek. Performance intensity pada teori ini sama halnya 
dengan "kecepatan" saat mengendarai sebuah mobil. (Suryaputra \& Sutanto, 2012). Variabel dasar dari Performance Intensity adalah duration-days dan work-days / time consumption. Duration-days adalah besarnya pencapaian kerja untuk mengurangi durasi dari aktivitas tersebut sebesar satu hari, sedangkan work-days / time consumption adalah hari yang direncanakan untuk menyelesaikan suatu pekerjaan berdasarkan kalender proyek.

Duration-days pada dasarnya memiliki arti yang sama dengan durasi aktivitas, namun ada sedikit perbedaan, yaitu duration-days memiliki nilai. Pemberian nilai dari duration-days ini ditentukan oleh penyelesaian dari volume pekerjaannya. Jumlah total duration-days dalam suatu satuan waktu tertentu disebut work performance (Woolf, 2007, p.139). Di bawah ini akan ditampilkan contoh perhitungan dan penentuan duration-days yang dapat dilihat pada Gambar 2.

\begin{tabular}{|c|c|c|c|c|c|}
\hline \multirow{2}{*}{ Aktivitas } & \multirow{2}{*}{$\begin{array}{c}\text { Durasi } \\
\text { (hari) }\end{array}$} & \multicolumn{5}{|c|}{ Hari ke- } \\
\cline { 3 - 6 } & 2 & 1 & 2 & 3 & 4 \\
\hline A & 2 & 1 & & \\
\hline B & 4 & 1 & 1 & 1 & 1 \\
\hline
\end{tabular}

Gambar 2. Duration-Days Barchart Rencana

Dapat dilihat bahwa aktivitas A direncanakan selesai dalam 2 hari, maka untuk mengurangi 1 duration-days, volume pekerjaan yang harus dicapai adalah $100 \% / 2$ hari $=50 \%$, sedangkan aktivitas $\mathrm{B}$, volume pekerjaan yang perlu dicapai untuk mengurangi 1 duration-days adalah $100 \% / 4$ hari $=25 \%$

Setelah itu perlu dilakukan pengamatan aktual di lapangan, misal data aktual memberikan informasi pada akhir hari pertama, aktivitas A selesai sebesar $40 \%$ dari volume total aktivitas $\mathrm{A}$ sedangkan aktivitas B selesai $60 \%$ dari volume total aktivitas B, maka kejadian ini dapat digambarkan pada Gambar 3.

AKTUAL
\begin{tabular}{|c|c|c|c|c|c|}
\hline \multirow{2}{*}{ Aktivitas } & \multirow{2}{*}{$\begin{array}{c}\text { Durasi } \\
\text { (hari) }\end{array}$} & \multicolumn{4}{|c|}{ Hari ke- } \\
\hline A & 2 & 0 & 2 & 3 & 4 \\
\hline B & 4 & 2 & & & \\
\hline
\end{tabular}

Gambar 3. Duration-Days Barchart Aktual (monitoring)

Pada aktivitas $\mathrm{A}$ dituliskan 0 dikarenakan tidak mencapai volume yang diperlukan untuk mengurangi 1 duration-days (50\%)

Pada aktivitas $\mathrm{B}$ dituliskan 2 dikarenakan mencapai volume yang diperlukan untuk mengurangi 2 duration-days (50\%) dan belum mencapai duration-days ke 3 (75\%)

Di dalam metode Performance Intensity terdapat beberapa rumus yang digunakan untuk mengetahui status proyek, apakah lebih cepat, tepat waktu maupun terlambat. Rumus-rumus tersebut antara lain : (Woolf, 2007, p.139).

1. Planned Performance Intensity (PPI)

PPI adalah Performance Intensity yang didapat per satuan waktu berdasarkan jadwal yang telah disusun sesuai rencana awal.

$$
\mathrm{PPI}=\frac{\text { Work performance rencana }}{\text { Waktu yang direncanakan }}
$$




\section{Actual Performance Intensity (API)}

API adalah Performance Intensity yang dihitung berdasarkan jadwal aktual dan progress sebenarnya melalui pengamatan di lapangan

$$
\mathrm{API}=\frac{\text { Work performance } \text { aktual }}{\text { Waktu yang digunakan }}
$$

\section{Catch-up Performance Intensity (CPI)}

CPI adalah perhitungan untuk mengetahui Performance Intensity yang harus dicapai pada periode berikutnya

$$
\mathrm{CPI}=\frac{\text { Work performance yang harus dicapai }}{\text { Waktu yang tersisa }}
$$

\section{Cruise Control Period (CCP)}

CCP adalah rata - rata PPI dari awal proyek hingga periode saat ini. Digunakan untuk mengetahui status waktu proyek sampai pada periode yang dihitung sampai akhir periode saat ini.

$\mathrm{CCP}=\frac{\text { Total Duration days yang dicapai hingga saat ini }}{\text { Waktu dari awal sampai dengan akhir periode saat ini }}$

CPM adalah suatu teknik perencanaan dengan analisis jaringan (network) berdasarkan ketergantungan antar aktivitas yang ada dalam proyek. CPM adalah suatu metode perencanaan penjadwalan proyek konstruksi yang dapat menunjukan aktivitas-aktivitas kritisnya. (Schexnayder \& Clifford, 2004). Ada 2 metode diagram dari CPM yaitu Activity On Arrow (AOA) dan Activity On Node (AON). Di dalam penentuan waktu ke dua metode tersebut terdapat forward pass yang terdiri dari ES (Early Start) dan EF (Early Finish) dan backward pass yang terdiri dari LS (Latest Start) dan LF (Latest Finish). Hal ini dapat dirumuskan sebagai berikut:

- $\quad \mathrm{EF}=\mathrm{ES}+$ duration

- $\quad \mathrm{LS}=\mathrm{LF}-$ duration

Penentuan dari critical path dapat dilihat per aktivitas, dan aktivitas tersebut merupakan aktivitas kritis apabila ES = LS. Critical path merupakan serangkaian aktivitas-aktivitas yang ada, yang tidak dapat ditunda jika proyek ingin selesai tepat pada waktunya.

Float adalah jangka waktu yang merupakan ukuran batas toleransi keterlambatan suatu aktivitas non kritis. Float dapat dibedakan sebagai berikut:

- $\quad$ Total float adalah jumlah total waktu yang dimiliki oleh suatu aktivitas yang dapat ditunda (aktivitas non kritis) tanpa mempengaruhi durasi proyek secara keseluruhan. Total float dapat dirumuskan sebagai berikut :

Total float $=$ LS - ES = LF - EF

- $\quad$ Free float adalah jumlah waktu yang dimiliki oleh suatu aktivitas yang dapat ditunda (aktivitas non kritis) tanpa mempengaruhi early start aktivitas sesudahnya. Free float dapat dirumuskan sebagai berikut :

Free float $=\mathrm{ES}($ aktivitas B) $-\mathrm{EF}$ (aktivitas A)

Monitoring adalah kegiatan pengamatan jalannya aktivitas di lapangan secara langsung. Hal ini bertujuan untuk memastikan agar durasi aktivitas tetap sesuai deangan rancana awal. Pada saat melakukan monitoring, sangat penting untuk membuat dokumentasi / catatan terhadap actual work dan durasi. Hasil dokumentasi / catatan tersebut akan dibandingkan dengan as plan schedule yang merupakan langkah controlling

Pada tahap monitoring metode Performance Intensity, pertama diperlukan adanya as plan schedule sebagai tolak ukur (standard yang diharapkan). Kemudian dilakukan pencatatan 
actual work di lapangan yang dibuat dalam bentuk persen, sesuai hasil pekerjaan aktual di lapangan. Setelah itu dilakukan perhitungan duration-days aktual, kemudian dilakukan analisis kinerja waktu yang dapat diketahui berdasarkan dari perhitungan rumus - rumus metode Performance Intensity.

1. Status waktu proyek per periode

Status waktu proyek per periode dapat diketahui dengan membandingkan antara PPI dengan API. Dengan melakukan perbandingan tersebut, maka dapat diketahui apakah kinerja waktu proyek pada periode tersebut lebih cepat,atau sama, maupun lebih lambat dari jadwal yang direncanakan.

a. $\mathrm{API}<\mathrm{PPI}$

Kondisi di atas menunjukkan bahwa kinerja waktu proyek pada periode tersebut lebih lambat dari jadwal yang direncanakan.

b. $\mathrm{API}=\mathrm{PPI}$

Kondisi di atas menunjukkan bahwa kinerja waktu proyek pada periode tersebut sama dengan jadwal yang direncanakan

c. $\mathrm{API}>\mathrm{PPI}$

Kondisi di atas menunjukkan bahwa kinerja waktu proyek pada periode tersebut lebih cepat dari jadwal yang direncanakan.

2. Status waktu proyek secara keseluruhan

Status waktu pada proyek secara keseluruhan dapat diketahui dengan membandingkan antara API kumulatif rata-rata dari periode awal sampai dengan periode yang dihitung dengan CCP yang direncanakan untuk dicapai pada periode tersebut. Dengan perbandingan tersebut dapat diketahui apakah kinerja waktu proyek secara keseluruhan sampai pada periode tersebut lebih cepat, atau sama, maupun lebih lambat dari jadwal yang direncanakan. Dengan mengetahui kinerja waktu proyek secara keseluruhan, maka dapat diambil langkah - langkah yang diperlukan untuk mempertahankan laju proyek sesuai dengan jadwal rencana.

a. API kumulatif rata-rata $<$ CCP

Kondisi di atas menunjukkan bahwa kinerja waktu proyek yang dicapai dari awal sampai dengan periode tersebut lebih lambat dari pencapaian yang direncanakan sampai dengan periode tersebut.

b. API kumulatif rata-rata $=\mathrm{CCP}$

Kondisi di atas menunjukkan bahwa kinerja waktu proyek yang dicapai dari awal sampai dengan periode tersebut sesuai dengan pencapaian yang direncanakan sampai dengan periode tersebut.

c. API kumulatif rata-rata $>\mathrm{CCP}$

Kondisi di atas menunjukkan bahwa kinerja waktu proyek yang dicapai dari awal sampai dengan periode tersebut lebih cepat dari pencapaian yang direncanakan sampai dengan periode tersebut.

3. Prediksi selesainya proyek

Dengan mengetahui API kumulatif rata-rata yang dicapai sampai dengan periode tersebut, maka tanggal selesai proyek secara aktual dapat diprediksi. Prediksi hari yang dibutuhkan untuk menyelesaikan proyek menurut jadwal aktual dihitung dengan membagi sisa total duration-days aktual dengan API kumulatif rata-rata sampai pada periode tersebut. Prediksi hari yang didapat dari perhitungan kemudian ditambah dengan tanggal akhir periode tersebut sehingga mendapat tanggal selesainya proyek tersebut.

Prediksi hari untuk selesai $\quad=\frac{\text { Total Duration-days Tersisa }}{\text { API kumulatif rata-rata }}$

Prediksi tanggal selesai = Tanggal akhir periode + hari untuk selesai

Pada tahap monitoring metode CPM, ada 3 langkah yang perlu ditempuh, yaitu:

1. Adanya as plan schedule sebagai tolak ukur (standard yang diharapkan)

2. Mengukur dan mencatat hasil prestasi pekerjaan. 
- Actual start date dan finish date

- Perubahan urutan aktivitas

3. Mengevaluasi hasil prestasi actual dengan standard prestasi yang diharapkan.

\section{METODOLOGI PENELITIAN}

Berikut adalah kerangka penelitian yang akan dilakukan yang dapat dilihat pada Gambar 4:

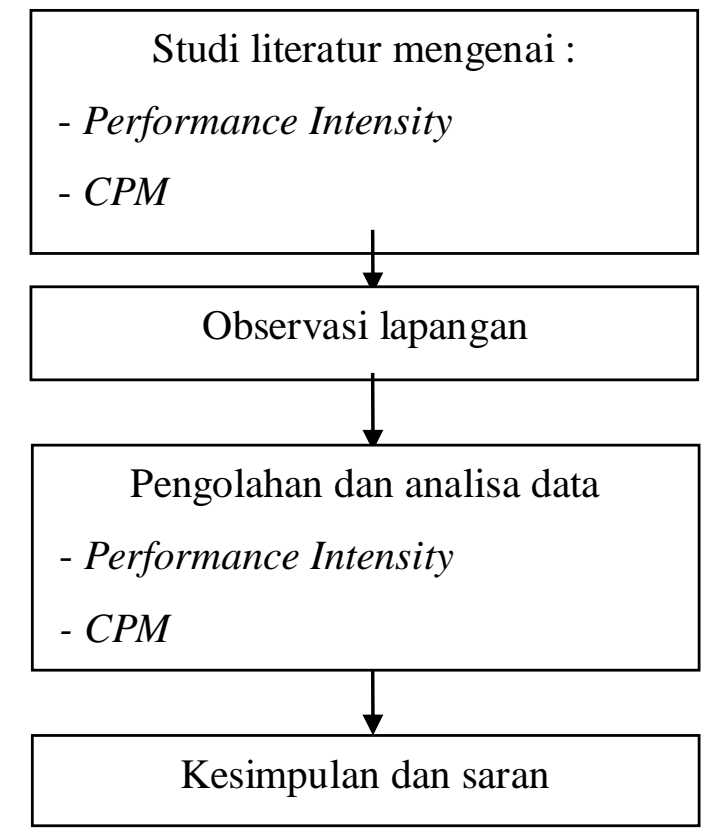

Gambar 4. Kerangka Langkah-Langkah Penelitian

Sebagai bahan penelitian, studi kasus akan diaplikasikan pada sebuah proyek hotel di Surabaya. Proses observasi lapangan bertujuan untuk pengumpulan data progress lapangan yang dilakukan dengan cara pengamatan langsung di lokasi proyek yang dimulai pada tanggal 15 September 2014 sampai 23 November 2014 (10 periode).

Pada metode Performance Intensity, hal pertama yang dilakukan adalah membuat barchart dengan duration-days di dalamnya dengan batasan pekerjaan struktur,dinding,tangga dari master plan schedule yang didapat dari kontraktor. Kemudian dilakukan monitoring di lapangan setiap hari untuk mendapatkan actual start, actual finish, persentase selesai tiap aktivitas. Setelah itu dilakukan perhitungan menggunakan rumus-rumus untuk menentukan prediksi tanggal akhir proyek setiap akhir periode.

Pada metode CPM, dibuat jadwal dengan batasan pekerjaan struktur,dinding,tangga dengan menggunakan software Microsoft Project. Kemudian dilakukan monitoring di lapangan untuk mendapatkan actual start, actual finish, persentase selesai tiap aktivitas. Setelah itu dilakukan analisa prediksi tanggal akhir proyek mingguan dengan analisa Microsoft Project.

\section{ANALISA DAN PEMBAHASAN}

Berikut adalah ringkasan planning awal durasi 189 hari yang dapat dilihat pada Tabel 1. 
Tabel 1. Planning Awal Proyek

\begin{tabular}{|c|c|c|c|c|}
\hline $\mathrm{NO}$ & AKTIVITAS & DURASI & START & FINISH \\
\hline 1 & Proyek Hotel & 189 days & $15 / 09 / 2014$ & $22 / 03 / 2015$ \\
\hline 2 & Pekerjaan Basement & 7 days & $15 / 09 / 2014$ & $21 / 09 / 2014$ \\
\hline 3 & Pekerjaan Struktur & 70 days & $15 / 09 / 2014$ & $23 / 11 / 2014$ \\
\hline 4 & Lantai 1 & 14 days & $22 / 09 / 2014$ & $05 / 10 / 2014$ \\
\hline 5 & Lantai 2 & 14 days & 06/10/2014 & $19 / 10 / 2014$ \\
\hline 6 & Lantai 3 & 14 days & 20/10/2014 & $02 / 11 / 2014$ \\
\hline 7 & Lantai 4 & 14 days & $03 / 11 / 2014$ & $16 / 11 / 2014$ \\
\hline 8 & Lantai 7 & 21 days & $15 / 09 / 2014$ & 05/10/2014 \\
\hline 9 & Zone 1 & 14 days & $15 / 09 / 2014$ & $28 / 09 / 2014$ \\
\hline 10 & Zone 2 & 14 days & $22 / 09 / 2014$ & $05 / 10 / 2014$ \\
\hline 11 & Lantai 8 & 21 days & $29 / 09 / 2014$ & $19 / 10 / 2014$ \\
\hline 12 & Zone 1 & 14 days & 29/09/2014 & $12 / 10 / 2014$ \\
\hline 13 & Zone 2 & 14 days & 06/10/2014 & $19 / 10 / 2014$ \\
\hline 14 & Lantai 9 & 21 days & $13 / 10 / 2014$ & $02 / 11 / 2014$ \\
\hline 15 & Zone 1 & 14 days & $13 / 10 / 2014$ & $26 / 10 / 2014$ \\
\hline 16 & Zone 2 & 14 days & $20 / 10 / 2014$ & $02 / 11 / 2014$ \\
\hline 17 & Lantai Atap 1 & 21 days & $27 / 10 / 2014$ & $16 / 11 / 2014$ \\
\hline 18 & Zone 1 & 7 days & $27 / 10 / 2014$ & $02 / 11 / 2014$ \\
\hline 19 & Zone 2 & 14 days & $03 / 11 / 2014$ & $16 / 11 / 2014$ \\
\hline 20 & Lantai Atap 2 & 7 days & $17 / 11 / 2014$ & $23 / 11 / 2014$ \\
\hline 21 & Pekerjaan Shearwall & 49 days & $15 / 09 / 2014$ & $02 / 11 / 2014$ \\
\hline 22 & Lantai 6 & 7 days & $15 / 09 / 2014$ & $21 / 09 / 2014$ \\
\hline 23 & Lantai 7 & 14 days & $22 / 09 / 2014$ & 05/10/2014 \\
\hline 24 & Lantai 8 & 14 days & 06/10/2014 & $19 / 10 / 2014$ \\
\hline 25 & Lantai 9 & 14 days & $20 / 10 / 2014$ & $02 / 11 / 2014$ \\
\hline 26 & Pekerjaan Dinding & 154 days & $20 / 10 / 2014$ & $22 / 03 / 2015$ \\
\hline 27 & Pekerjaan Pas. Dinding Dalam & 77 days & $20 / 10 / 2014$ & $04 / 01 / 2015$ \\
\hline 28 & Pekerjaan Pas. Dinding Luar & 77 days & $20 / 10 / 2014$ & $04 / 01 / 2015$ \\
\hline 29 & Pekerjaan Plester Acian & 77 days & $17 / 11 / 2014$ & $01 / 02 / 2015$ \\
\hline 30 & Pekerjaan Cat Interior & 84 days & 29/12/2014 & $22 / 03 / 2015$ \\
\hline 31 & Pekerjaan Cat Eksterior & 84 days & $29 / 12 / 2014$ & $22 / 03 / 2015$ \\
\hline 32 & Pekerjaan Tangga & 77 days & 06/10/2014 & $21 / 12 / 2014$ \\
\hline 33 & Pekerjaan Struktur Tangga & 63 days & 06/10/2014 & $07 / 12 / 2014$ \\
\hline 34 & Pekerjaan Railing Tangga & 63 days & $13 / 10 / 2014$ & $14 / 12 / 2014$ \\
\hline 35 & Stair Nosing Tangga & 63 days & $13 / 10 / 2014$ & $14 / 12 / 2014$ \\
\hline 36 & Finishing Lantai Tangga & 63 days & $20 / 10 / 2014$ & $21 / 12 / 2014$ \\
\hline 37 & Finish & 0 days & $22 / 03 / 2015$ & 22/03/2015 \\
\hline
\end{tabular}

Setelah itu dilakukan monitoring dan analisa tiap periode selama 10 periode dan didapatkan hasil analisa yang terlihat pada Tabel 2. dan Gambar 5. 
Tabel 2. Analisa Akhir Proyek Metode CPM dan Performance Intensity

\begin{tabular}{|c|c|c|c|c|}
\hline Periode & CPM & Tanggal akhir & PI & Tanggal akhir \\
\hline 1 & 192 & $25 / 03 / 2015$ & 183 & $16 / 03 / 2015$ \\
\hline 2 & 199 & $01 / 04 / 2015$ & 154 & $15 / 02 / 2015$ \\
\hline 3 & 185 & $18 / 03 / 2015$ & 155 & $16 / 02 / 2015$ \\
\hline 4 & 182 & $15 / 03 / 2015$ & 128 & $20 / 01 / 2015$ \\
\hline 5 & 186 & $19 / 03 / 2015$ & 123 & $15 / 01 / 2015$ \\
\hline 6 & 190 & $23 / 03 / 2015$ & 119 & $10 / 01 / 2015$ \\
\hline 7 & 184 & $17 / 03 / 2015$ & 127 & $19 / 01 / 2015$ \\
\hline 8 & 185 & $18 / 03 / 2015$ & 135 & $27 / 01 / 2015$ \\
\hline 9 & 175 & $08 / 03 / 2015$ & 138 & $28 / 01 / 2015$ \\
\hline 10 & 175 & $08 / 03 / 2015$ & 140 & $30 / 01 / 2015$ \\
\hline
\end{tabular}

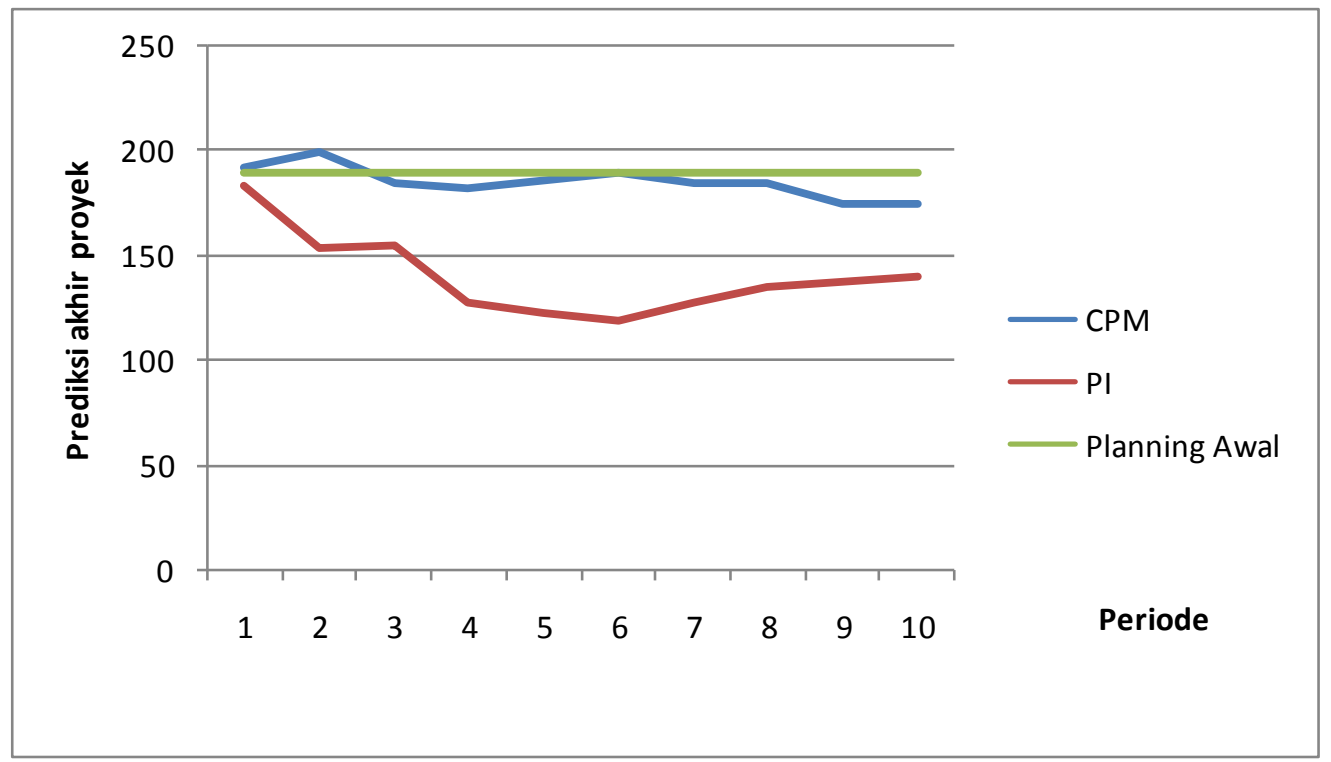

Gambar 5. Perbandingan Prediksi Akhir Proyek 2 Metode

\section{KESIMPULAN}

- Dengan menggunakan metode Performance Intensity selama 10 periode didapatkan hasil bahwa proyek ini sejak periode awal mengalami progress yang lebih cepat dari yang direncanakan. Range selesai proyek antara 123-185 hari. Dengan menggunakan metode CPM selama 10 periode didapatkan hasil analisa akhir proyek mempunyai range 175-199 hari.

- Seperti terlihat pada poin 1, analisa kedua metode ini mengalami perbedaan. Range dari analisa metode CPM lebih kecil daripada analisa metode Performance Intensity. Hal ini dikarenakan prediksi metode Performance Intensity menggunakan kecepatan rata-rata proyek kumulatif yang terus berubah-ubah setiap periodenya.

\section{DAFTAR REFERENSI}

Husein, A. (2009). Manajemen Proyek. Andi Offset, Yogyakarta.

Proboyo, B. (1998). Keterlambatan Waktu Pelaksanaan Proyek : Klasifikasi dan Peringkat dari Penyebab-Penyebabnya. Tesis pasca-sarjana - Universitas Kristen Petra, Surabaya. 
Schexnayder \& Clifford. (2004). Construction Management Fundamentals. Mcgraw-Hill Construction, Boston.

Suryaputra, G. \& Sutanto, S. (2012). Kajian Awal Mengenai Performance Intensity (Momentum Management) untuk Mengukur Kinerja Waktu Proyek Konstruksi.

Woolf, M. B. (2007). Faster Construction Project with Cpm Scheduling. The McGraw-Hill Companies. 